\title{
Editorial - Urban and spatial challenges in South Africa: Continuing (and extending) the conversation
}

During 2018 the World Bank issued an important systematic country diagnostic report on South Africa . Its central message was that whilst the country has come a long way since the advent of democracy in 1994, South Africa has recorded "an incomplete transition". In particular, it was argued that notwithstanding political transition to majority rule that the economic transition from a system of exclusion under segregation and apartheid remained still to be completed. Although the title is sometimes contested with Brazil, South Africa remains the world's most unequal country. In addressing exclusion the World Bank argues that the imperative is for expanded job creation, most especially for the country's youth. Several key constraints are identified for the reduction of poverty and inequality in South Africa. These include insufficient skills, the highly skewed distribution of land and productive assets, and low levels of competition and integration into global value chains, which impacts in particular opportunities for small enterprise development. Two further critical issues are the limited or expensive spatial connectivity associated with under-serviced historically disadvantaged settlements and the overarching threats posed to economic and social development in South Africa by the calamity of climate change (World Bank, 2018).

It is against this backdrop of the enormous policy challenges facing the country that this collection of fifteen papers seeks to provide new research and fresh policy insights concerning certain of the urban and spatial challenges that confront South Africa. Arguably, no set of papers could possibly address all the multiple and complex questions raised by the 2018 World Bank diagnostic report about South Africa's 'incomplete transition'. Indeed, this collection was never conceived with any such an objective in mind. The special theme issue in preparation well before the appearance of the landmark World Bank report - has more modest goals. During 2013 the editors of Urbani izziv encouraged the preparation of a group of research papers which were published in July 2014 as a special issue under the broad title of "Addressing South Africa's Urban Challenges" (Rogerson et al., 2014). Five years later the journal editors accepted a proposal for a second special South African issue. This particular collection of 15 articles is the end-product. It was prepared within the context of the stated mission of Urbani izziv being the dissemination of new knowledge and discussion of contemporary spatial issues through top quality scholarly articles. The collection here continues the multiple conversations about the urban and spatial challenges facing South Africa that began to be discussed in this journal five years ago (Rogerson et al., 2014). Subsequently, these conversations have been enriched also by the appearance of a number of other South African research contributions which have been published in Urbani izziv between 2014 and 2018 (Campbell, 2016; de Vries \& Kotze, 2016; Rogerson \& Rogerson, 2016). In addition, the collection seeks to introduce certain new themes of growing interest to South African urban and spatial researchers and which are embedded in an appropriate international research scholarship. 
Within the papers included in this special issue are represented several established themes which are of core interest to Urban izziv. These include policy-relevant considerations around national spatial planning, regional and local development, housing, and changing urban landscapes. Environmental concerns and gender are also critical foci for extended investigation. Beyond these issues other research foci are under scrutiny in this special issue. As Southern Africa is a region of the world that is anticipated to experience some of the worst impacts of global warming (Ziervogel et al., 2014), the theme of climate change is interrogated both as a threat and opportunity. Moreover, in respect of South Africa's policy imperative for job creation, the sector of tourism as a labour-absorptive activity is gathering increased policy attention. Accordingly, in this collection questions are raised around the role of tourism and recreation particularly in the context of the country's emerging new planning orientation towards the 'blue economy'. Finally, as the 'incomplete transition' of contemporary South Africa can never be understood without an understanding of the legacy of the past, the collection includes some historical reflections on issues around urban economic development issues, in this case surrounding the critical sector of tourism. Overall, it is submitted that this special issue contributes to further advance the body of research and scholarship about urban development, planning and the spatial challenges of South Africa.

Jayne M. Rogerson, School of Tourism \& Hospitality, College of Business and Economics, University of Johannesburg, Johannesburg, South Africa (jayner@uj.ac.za)

\section{Acknowledgements}

In encouraging the preparation of this special issue my thanks go to the past and present editors of Urbani izziv. Damjana Gantar is thanked for commissioning this collection of papers and she has provided extensive support to the completion of this collection and bringing it to the stage of final production. Major editorial assistance on this collection of papers was provided by Arabella Rogerson, University of Cape Town. Funding support from University of Johannesburg, in particular the College of Business \& Economics, is acknowledged.

\section{References}

Campbell, M. (2016) A great place and yet another declining small town: The case of Clarens, South Africa. Urbani izziv, 27(2), pp. 138-148. DOI: 10.5379/urbani-izziv-en-2016-27-02-005

De Vries L. \& Kotze, N. (2016) The revitalisation of parks and open spaces in downtown Johannesburg. Urbani izziv, 27(1), pp. 123-131. DOI: 10.5379/urbani-izziv-en-2016-27-01-003

Rogerson, C.M. \& Rogerson, J.M. (2016) Intra-urban spatial differentiation of tourism: Evidence from Johannesburg, South Africa. Urbani izziv, 27(2), pp. 125-137. DOI: 10.5379/urbani-izziv-en-2016-2702-004

Rogerson, C. M., Rogerson, J. M. \& Kotze, N. (eds.) (2014) Addressing South Africa's Urban Challenges. Urbani izziv, 25(Supplement), pp. S1-S4. DOI:10.5379/urbani-izziv-en-2014-25-supplement-000

World Bank (2018) An Incomplete Transition: Overcoming the Legacy of Exclusion in South Africa. Group Report No. 125838-ZA. Washington DC, World Bank.

Ziervogel, C., New, M., Archer van Garderen, E., Midgley, G., Taylor, A., Hamann, R., Stuart-Hill, S., Myers, J. \& Warburton, M. (2014) Climate change impacts and adaptation in South Africa. WIREs Climate Change, 5(September/October), pp. 605-620. DOI: 10.1002/wcc.295 